\title{
Adolescent girls with idiopathic scoliosis $<40$ degrees, treated with TLSO brace, reveal less clinical deformity than non-treated girls having similar scoliosis angle

\author{
Edyta Kinel ${ }^{1}$, Tomasz Kotwicki ${ }^{* 2}$, Wanda Stryła ${ }^{1}$ and Andrzej Szulc ${ }^{2}$
}

\author{
Address: ${ }^{1}$ Department of Rehabilitation, University of Medical Sciences of Poznan, ul. 28 Czerwca 1956 roku nr 135; 61-545 Poznan, Poland and \\ ${ }^{2}$ Department of Pediatric Orthopedics and Traumatology, University of Medical Sciences of Poznan, ul. 28 Czerwca 1956 roku nr 135; 61-545 \\ Poznan, Poland \\ Email: Tomasz Kotwicki* - kotwicki@amp.edu.pl \\ * Corresponding author
}

from 4th International Conference on Conservative Management of Spinal Deformities

Boston, MA, USA. 13-16 May 2007

Published: 12 October 2007

Scoliosis 2007, 2(Suppl I):SI6 doi:I0.II86/I748-7I6I-2-SI-SI6

This abstract is available from: http://www.scoliosisjournal.com/content/2/SI/SI6

(c) 2007 Kinel et al; licensee BioMed Central Ltd.

\section{Objective}

The goal was to compare clinical deformity among two groups of girls with adolescent idiopathic scoliosis (AIS), with curves <40 degrees: Group 1 was treated with a thoracolumbar sacral (TLSO) orthosis; and Group 2 was nontreated.

\section{Study design}

Group 1 consisted of twenty-four girls wearing the brace and Group 2 consisted of twenty-six girls without the brace, matched for Cobb angle. We examined the hypothesis that girls wearing the brace for more than six months, when compared to scoliotics without brace, may present distinct morphology of the trunk, in spite of having similar Cobb angle. Inclusion criteria: Female gender, a diagnosis of AIS, age 10-16 years, out of brace Cobb angle minimum 25 degrees, maximum 40 degrees. The braced group consisted of girls wearing a TLSO brace (Cheneau) a minimum of sixteen hours per day for more than six months. The unbraced group consisted of girls first seen for their spinal deformity, previously not treated.

\section{Methods}

Angle of trunk rotation (ATR) at three levels of the spine upper thoracic (Th1-Th5), main thoracic (Th5-Th12), lumbar or thoracolumbar (Th12-L4) - was measured using a scoliometer [1]. The maximal angle was noted at each level and the sum of three levels was calculated. Posterior trunk symmetry index (POTSI) was measured using surface topography [2].

\section{Results}

Cobb angle was $35.0 \pm 4.8$ degrees in braced and $33.0 \pm$ 4.9 degrees in un-braced patients (difference not significant, unpaired t-test). The age was $14.1 \pm 1.6$ years in Group 1 and $13.1 \pm 1.9$ years in Group $2(\mathrm{p}=0.046$, unpaired t-test). Risser sign value was less than three in twelve girls from Group 1 and in twenty-three girls from Group 2. Both groups presented similar curve patterns. The value of ATR in the main curvature was $8.4 \pm 2.7$ degrees in Group 1 and $11.4 \pm 2.7$ degrees in group 2 (difference highly significant, $\mathrm{p}=0.0003$, unpaired t-test). The value of the sum of ATR at three levels of the trunk was $12.8 \pm 4.6$ degrees in Group 1 and $16.5 \pm 3.8$ degrees in Group 2 (difference significant, $\mathrm{p}=0.0038$, unpaired ttest). The POTSI did not differ significantly between the groups $(\mathrm{p}=0.18)$.

\section{Conclusion}

Girls with Cobb angle of 25 to 40 degrees, wearing the brace, revealed less clinical deformity than non-treated girls having similar radiological deformity. Evaluation of results of scoliosis treatment should consider clinical deformity and not be limited to radiological data. 


\section{References}

I. Bunnell WP: An objective criterion for scoliosis screening. J Bone Joint Surg 1984, 66A: I 38I-1387.

2. Asher M, Lai S, Burton D, Manna B: Maintenance of trunk deformity correction following posterior instrumentation and arthrodesis for idiopathic scoliosis. Spine 2004, 29: 1782-8.

Publish with Bio Med Central and every scientist can read your work free of charge

"BioMed Central will be the most significant development for disseminating the results of biomedical research in our lifetime. " Sir Paul Nurse, Cancer Research UK

Your research papers will be:

- available free of charge to the entire biomedical community

- peer reviewed and published immediately upon acceptance

- cited in PubMed and archived on PubMed Central

- yours - you keep the copyright

Submit your manuscript here:

http://www.biomedcentral.com/info/publishing_adv.asp 